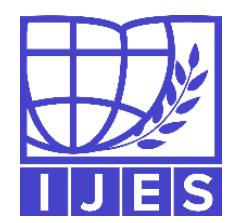

Article History Received: 23.11 .2021 Accepted: 20.12 .2021 Published: 25.12.2021
International Journal of Education and Science print ISSN: 2618-0553; online ISSN: 2618-0561; DOI: 10.26697/ijes Journal Website: https://ijes.world

SOCIAL AND BEHAVIORAL SCIENCES

Education

ORIGINAL RESEARCH

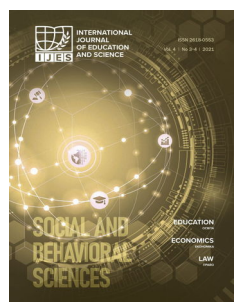

\title{
Leadership in Young Filipino Children: An Exploratory Sequential Mixed Methods Study Juzy LAYGO-SAGUIL ${ }^{1 *}$
}

${ }^{I}$ School of Education, Philippine Women's University, Philippines

* Corresponding Author's Email: jlsaguil@pwu.edu.ph

\section{Лідерство серед філіппінських дітей молодшого віку: попереднє послідовне дослідження змішаними методами}

Лейго-Сагіль Дж. ${ }^{1}$

${ }^{1}$ Школа освіти, Філіппінський жіночий університет, Філіппіни

\section{Лидерство среди филиппинских детей младшего возраста: предварительное последовательное исследование смешанными методами Лейго-Сагиль Дж. ${ }^{1}$ \\ ${ }^{1}$ Школа образования, Филиппинский женский университет, Филиппины}

\begin{abstract}
Background: This study explores the early childhood education teachers' recognition of leadership characteristics among Filipino kindergarten pupils. Framed by the theory on progressive education by Dewey, this study is designed to fill the gap in the literature on child leadership qualities and behavior.

Purpose: To explore how early childhood classroom teachers, recognize leadership behavior in young children. Materials and Methods: An exploratory sequential mixed method research design was selected in order to broadly explore and analyze the kindergarten teachers' perception of child leadership. This utilized descriptive research design using both qualitative and quantitative data. Focus group discussion was first conducted with 10 private school teachers for the qualitative part of the study. 25 items of the leadership in young children survey were prepared according to the results obtained from the discussion. The survey was assessed using a Likert-type response format. 95 child development center teachers, selected through purposive sampling technique, participated in the quantitative part. Results: Findings revealed that the leadership descriptors that emerged based on the focus group discussion are: sought out by peers, responsible; empathetic; communicator; and collaborative. These descriptors were the basis for the development of a child leadership model, the Filipino child leadership framework.

Conclusions: The growth of positive social-leadership traits in young children could be encouraged through the enhancement of the teaching skills of Filipino preschool teachers, and therefore, the delivery of quality education in the kindergarten level.

Keywords: exploratory sequential mixed methods, kindergarten teachers, leadership, young Filipino children, education, survey.
\end{abstract}

DOI: https://doi.org/10.26697/ijes.2021.3.2 JEL: I20, I21

UDC: $37.04-053: 37.013 .21(599)$

Cite this article as: Laygo-Saguil, J. (2021). Leadership in young Filipino children: An exploratory sequential mixed methods study. International Journal of Education and Science, 4(3-4), 24-32. https://doi.org/10.26697/ijes.2021.3.2

(C) 2021 Laygo-Saguil J.

Published by Archives of International Journal of Education and Science

Open Access under a Creative Commons "Attribution" 4.0 Worldwide

\section{Introduction}

Leadership has been called an essential component in social interaction and is an important social behavior in children. Researchers have observed leadership behavior in young children and suggested that these leadership behaviors be encouraged in early childhood classrooms. It follows that early-childhood education is a prime setting to study emerging social skills and leadership traits in order to explore ways to help young children gain the social and emotional competence necessary for lifelong success. 
In the Philippines, studies on leadership focusing on young children is scanty. Despite the extensive research about leadership, there is not much exploration addressing leadership in young children. Most leadership programs in the Philippines launched by the government and/or sponsored by other countries focus more on training for government positions and fail to represent other sectors especially education. Much of the investigation regarding leadership is focused on leadership styles and leadership characteristics of student leaders, and school principals and administrators. More specifically, little material is available to teachers' perception on leadership in young children. Evidently, no instrument is available to establish observable leadership characteristics in the early years. Hence, the purpose of this research is to explore how early childhood classroom teachers recognize leadership and how they could enhance the leadership potentials of young Filipino children in early childhood settings.

Being one of the pioneers in exploring leadership in young children in the Philippines, the study aimed at offering researchers and educators further understanding of the applicability of leadership to children, and how it could be nurtured in a developmentally appropriate manner, through the Leadership in Young Children Survey (LYCS) developed in this study. Moreover, the Filipino Child Leadership Framework drew from this study also proposed to contribute additional understanding in developing leadership skills among young Filipino children.

As such, it is hoped that this study would aid in enhancing the teaching and the learning process, leading to the development of learners who possess leadership skills that would enable them to be adaptive, collaborative, and globally competitive.

Literature reveals that children could be born with latent leadership abilities. Even at a young age, children exhibit leadership skills. Just as children learn other important skills, children can learn and build on these leadership skills through their experiences.

The premise is very evident in the study of Zembat et al. (2017) who reported that leadership skills can be taught and instruction should begin in the early years. The social aspects of leadership are becoming increasingly important and should be included in the early childhood curriculum. Likewise, the result of Ferland et al. (2015) research proved that the development of leadership skills is more favorable in childhood, as children can master them without pressure and having to overcome themselves. In the same manner, Evans (2014) also theorized that leadership could be taught, even to preschoolers or younger children than previously imagined because, regardless of age, they too have shown the aptitude for transformational learning. Montgomery and Kehoe (2015) also mentioned that children of all ages can take leadership roles.

The literature review likewise provided leadership characteristics prevalent among young children. Francis et al. (2016) reiterated that one of the means of leadership qualities formation in the preschool years is training and communication. Cansoy (2017), on the other hand, acknowledged that the most important leadership qualities that should be brought to students, according to the teachers' opinions, are communication skills, problem-solving skills, responsibility, honesty, and goal setting, respectively. Leadership skills of preschoolers include such qualities as honesty, fairness, and consistency, ability to direct the attention of others and to come up with new solutions in gaming activity, self-confidence, courage and determination, the ability to quickly establish contact with other children, activity, sociability, etc. (Epstein, 2014). The relationships created in preschool can have lasting effects because early positive feelings of going to school can impact a child's eagerness to participate in classroom activities. Fox et al. (2015), who collated leadership characteristics identified from learning domains in the literature, affirmed that as the domains overlap, one characteristic may be representative of more than one domain.

If young learners did not have skills in leadership or followership, the teacher could work to promote effective social skills that might help guide the learners toward effective leadership (Barthold, 2014). Teachers can model and teach the skills that will equip young learners to lead themselves and others in this hypercompetitive world, because the path to leadership among young learners are in their teachers' hands at school (Bradberry, 2015). These could be done through various strategies, including coaching, modeling, praising, direct teaching, or asking questions.

The aim of the study. To explore how early childhood classroom teachers, recognize leadership behavior in young children.

The study focuses on identifying and enhancing the leadership competencies among Filipino kindergarten children. Specifically, this paper answers the following questions:

1. How do the kindergarten teachers describe leadership among children?

2. What tool could be developed to identify the characteristics of a child leader, as drawn from the lens of Kindergarten teachers?

3. What framework could be designed based on the teachers' perception of the child leadership?

\section{Materials and Methods}

An exploratory sequential mixed methods research (MMR) design was selected in order to broadly explore and analyze the kindergarten teachers' perception of child leadership. This utilized a descriptive research design using both qualitative and quantitative data. In an exploratory design, qualitative data is first collected and analyzed, and themes are used to drive the development of a quantitative instrument to further explore the research problem (Berman, 2017).

\section{Participants}

10 private school teachers participated in the qualitative part of the study. 9 of the ten teachers are female. The average age of the teachers is 33 years. Kindergarten teachers from selected Child 
Development Centers in Pasay city were the respondents in the quantitative part of this study. 105 teachers, 95 kindergarten teachers participated in the survey. $100 \%$ of the participants are female. This ratio of the teachers' gender appears to be common in Philippine schools, especially kindergarten and elementary schools (Zepp, 2018).

Sampling Technique

Purposive sampling is guided by the main purpose and reason for conducting this study. Thus, the researcher selected the samples which she believed are capable of providing answers to the research questions. The convenient sampling method was used in determining the participants for the focus group discussion. Teachers from selected child development centers who are handling kindergarten pupils were purposively chosen as respondents for the quantitative part.

Data Gathering Procedure

This phase of the research focused on the formulation of the research objectives and laying out the strategies and activities in conducting the study. It also included the formulation of questions and coding of themes in the focus group discussion which led to the creation of the Leadership in Young Children Survey (LYCS).

Findings were achieved by applying the content analysis to the data obtained from the notes. Similar data are combined within the scope of certain concepts and themes in the content analysis and readers are ensured to interpret them in a way that they can understand. The data from the teachers were separately coded by the researcher. The list of the codes obtained after all data were encoded was carefully analyzed by the researcher. Then, themes were created by considering the similarities and differences of the codes obtained. At the third stage, the obtained themes were defined and edited by making them comprehensible. Finally, comments regarding the edited themes were made and the conclusions were achieved. In the discussion conducted with the teachers, the participants were named "teacher", and each one was given a number. Validation of the LYCS was conducted with the help of validation experts.

\section{Data Analysis and Interpretation}

The concepts of credibility and transferability are used instead of internal and external validity, and the concepts of consistency and verifiability are used instead of internal and external reliability in qualitative studies. The researcher used direct quotations in accordance with the nature of the data to ensure transferability. To ensure consistency, external researchers who are experts in the field were consulted for verifiability. The experts analyzed the data, checked the themes extracted from the codes, and evaluated and confirmed leadership descriptors. The written data for content analysis was prepared by transcribing them from audio into text form and was divided into coding units guided by the qualitative questions of the study. Reading and re-reading of the FGD transcripts were done to identify the themes and their interconnection (Oliveira, 2016). Texts and transcriptions in the data analysis are the exact conversation and based on the actual dialog of the respondents.

\section{Linking of the Two Strands of Data}

The linking of data happened at the design-level with the use of a sequential design, where the results from the first phase of the research which was the focus group discussion was used to build the second stage of the research design, which was the development of the LYCS. The qualitative approach provides data that can be measured on the dimension of how well teachers recognize leadership in young children. The quantitative approach provides teachers of early childhood education an opportunity to describe and identify child leadership qualities and characteristics. Then, the questionnaire which was prepared according to the results obtained from the discussion was distributed to a larger group of teachers.

The instrument was pilot tested and was verified using Cronbach's alpha. The result was 0.9674 which makes the instrument acceptable and ready for use.

\section{Results and Discussion}

Based on the focus group discussion, this study found that the participants have varied understanding and perception of leadership. The kindergarten teachers have a diverse recognition of who a child leader is. The first theme considered is: Sought out by peers. The literature reveals that child leadership is a process by which one person influences the thoughts, attitudes, and behaviors of other people (Mulovhedzi \& Mudzielwana, 2016) which means that leadership is the ability to get other people to do something significant that they might not otherwise do. This is supported by the following statements:

T7: A child leader is always chosen by his peers as group mate on the table, play mate and peer buddy during recess time.

T4: A child leader is always imitated by peers in the class even on the way he or she talks.

T7: A leader works with others well, and influences others to complete a task

Problem solver/carries out responsibility is the next child leadership descriptor that arose. Problem solving is among the important leadership qualities that should be brought to the learners. Identification of a problem, suggesting appropriate solutions and controlling the solutions are among the important steps of problem solving.

The following quotes highlighted the descriptor "problem solver/responsible":

T2: A child leader always finishes a task ahead and help other classmates who have difficulty accomplishing a certain task.

T4: A leader is disciplined/has good classroom management like if the class is noisy, the leader makes effort to keep the class organized.

T2: A leader plans/organizes tasks given step by step; not impulsive - during project making or performance - based activities, he/she checks the materials to be used before starting with the project.

Problem-solving has a special place in the preschool period as it is a skill that needs to be developed at young ages (Oguz \& Akyol, 2015). Through problemsolving skills, children learn to focus their thoughts on 
a subject, generate alternative solutions, conceptualize causation, and foresee the results.

Empathetic/sensitive to feelings of others is another theme that emerged based on the teachers' responses:

T7: A child leader manifests both cognitive and affective skills - the intelligence and emotional aspects. He is not only smart but what is important is that he also has a concern for others.

T4: A child leader is sensitive to the feelings of others, he assists his classmates who had a hard time in class.

T6: A child leader is respectful and not offensive to others. Yacat (2013) placed much weight on shared inner perception as the pivotal interpersonal value. For the Filipinos, it is described as involving tentative, exploratory, and improvisatory behavior intended to avoid offending or hurting other people. In a sense, it requires that a person actively senses or feels out the situation and the other person in social interaction, and carefully come up with appropriate behavior.

Another descriptor that emerged is communicates well/shows confidence. To be able to communicate comfortably in writing or verbally, to try to carefully listen and understand others, and to be able to take decisions together are among the important child leadership qualities.

T5: A leader has good communication and good reasoning skills.

T9: A child leader knows how to follow instructions and can express ideas in class confidently.

T2: A child leader speaks what is on his mind; he is not hesitant to voice what he wants and what he does not want.

The study of Labor (2017) narrated that Filipino student leaders are comfortable communicating with people within their social groups. Filipino values such as shame have been reframed: from shame to external propriety. Good communication skills, such as one's capacity to listen, are perceived as a necessity as this "allows and facilitates communication with followers". The teachers explained that being collaborative and cooperative is the ability of the individual to conform with their classmates and groupmates. It is important to note that social and interpersonal characteristics are necessary in order to lead. People who lead need to acquire a positive self-concept. Boas et al. (2014) ascertained that leaders who have a healthy selfconcept increase trust and respect from followers' selfconcepts. These are strong predictors of future achievement and healthy emotional adjustment. This is supported by the following quotes:

T5: A leader volunteers to do something like helping the teacher or helping a classmate.

T10: Leadership is being responsive to different situations in the classroom; a leader does not hesitate to do a task.

T2: A leader can work well alone or with other students and can adapt well to different situations.

The corresponding leadership characteristics provided in each leadership descriptor are the bases for the development of the LYCS.

Table 1 shows the mean results of the descriptors of leadership in young children.
The descriptor "Communicates well/shows confidence" got the highest mean of 3.24 among the top 5 descriptors and is interpreted as "Potential Leader". It could be noted that of the characteristics listed displays confidence when speaking and answering questions" is the only one that got the interpretation "High Potential Leader". This proves that a leader needs to express himself/herself well and relays information effectively.

Cimene and Aladano (2013) shared that to lead successfully in the Filipino context, a leader must be able to get along well with others without being controlling or abusive. Leaders are also able to connect with their members when they collaborate to accomplish important projects.

The descriptor "Empathetic and collaborative" got the same overall mean (3.13) and is interpreted as "Potential Leader". Working well and cooperating with others are distinct characteristics of a Filipino child leader. A child leader needs to be responsive, but sensitive to different situations. The result is supported by the work of Ilac (2011) who noted that Filipinos preferred a leader who is person-focused and groupcentered, but also knowledgeable. Respondents want a leader who is easy to talk to, listens with understanding and compassion, and cares about the others' welfare

The descriptor "Problem solver/carries out responsibilities" got an overall mean of 3.12 and an interpretation of "Potential Leader". This descriptor includes the following perceived characteristics: does assigned tasks well; can solve simple problems; can follow given instructions; is organized in school materials and activities; can make good decisions/choices. Gunindi (2017) described that in the problem-solving method, children and students take an active role in the education process. During the problem-solving phase, children are required assistance to gather, compare and evaluate necessary information to make a conclusion and assessment from them. This will make it easier for the individual's adaptation to life; because in this way, in school the child will have strength, courage, and the ability to solve the problems that he will face in life later.

The leadership descriptor "Sought out by peers" got the lowest mean (3.06) among the top five descriptors, but is still interpreted as "Potential Leader". Some of the leadership characteristics under this descriptor are: can be a model of appropriate behavior or skills for other children; is friendly and well-liked by others; can influence his/her classmates to do the tasks well; is trusted and followed by classmates; can take charge of a situation without being bossy. Abdigapbarova et al. (2016) considered that an important quality among preschool children with leadership skills is sociability, i.e. the ability to quickly establish contacts with other children and feel confident in a team. As shown by the results of the study, self-motivated children with leadership skills are able to attract other children with their ideas and thoughts. Children, who have organizational skills, easily find their way around any game situation and are able to quickly make the right decision. 
Table 1

Mean Results Obtained on Leadership in Young Children Survey

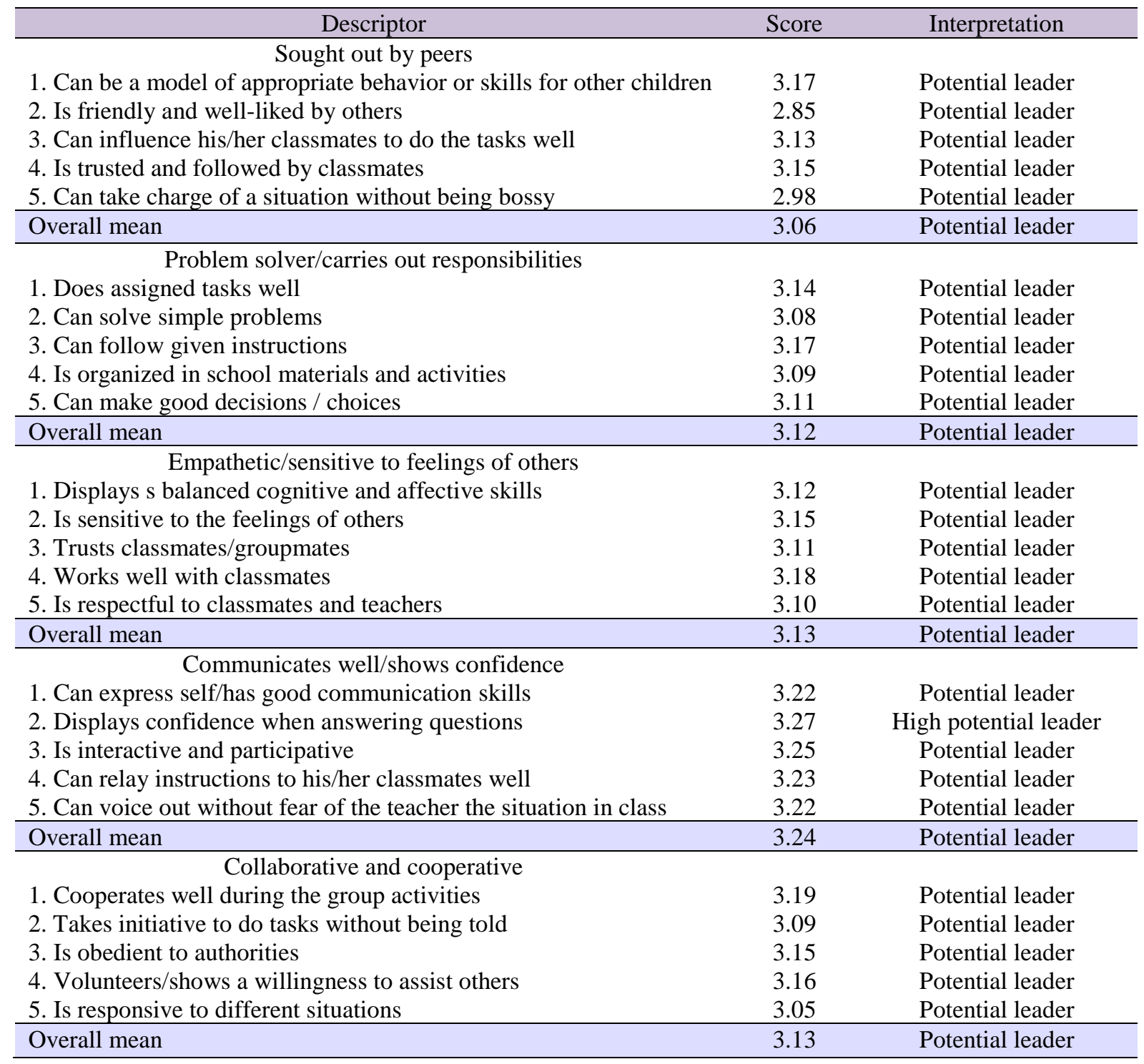

The Department of Education (DepEd) believes that kindergarten is the transition period from informal to formal literacy in which positive experiences must be nurtured to ascertain school readiness. As stated in the Kindergarten curriculum guide (Department of Education, Republic of the Philippines, 2012), extensive research has shown that this is the period of greatest growth and development, during which the brain continuously develops most rapidly and almost at its fullest. Thus, it is also the stage when leadership skills and abilities must be nurtured and enhanced. But what makes a Filipino child leader, and how do the kindergarten teachers perceive leadership among young children?

The Filipino child leadership model (Figure 1) illustrates the interconnections of the top five leadership characteristics which the Filipino child leader should possess as perceived by the kindergarten teachers (Laygo-Saguil, 2020).
This model explains the top five distinct characteristics a Filipino child leader should possess. The core of the model which is the Filipino child leader is represented by the color red. The color red is energizing and it provokes emotions and motivates us to take an action. The red color expresses pioneer spirit and leadership qualities and promotes ambition and determination.

A Filipino child leader who is sought out by peers is perceived to be chosen always by others to lead the group and to take charge of a situation. He is always imitated by peers, works well, and influences others. This is represented by the color yellow. The color yellow is related to learning. It is a color that resonates with the left (or logical) side of the brain, where it stimulates our mentality and perception. The color yellow inspires thought and curiosity and it is creative from a mental point of view - the color gives new ideas. The yellow color helps us find new ways of doing things. 
Another characteristic of a Filipino child leader is displaying responsibility at all times. A child leader makes his own decisions, solves problems creatively, and readily accepts responsibility. This is represented by the color blue. The blue color is reliable and

\section{Figure 1}

The Filipino Child Leadership Model responsible and radiates security and trust. The color blue can take control and do the right thing in difficult situations. The blue color needs order and planning in its life, including the way it lives and works.

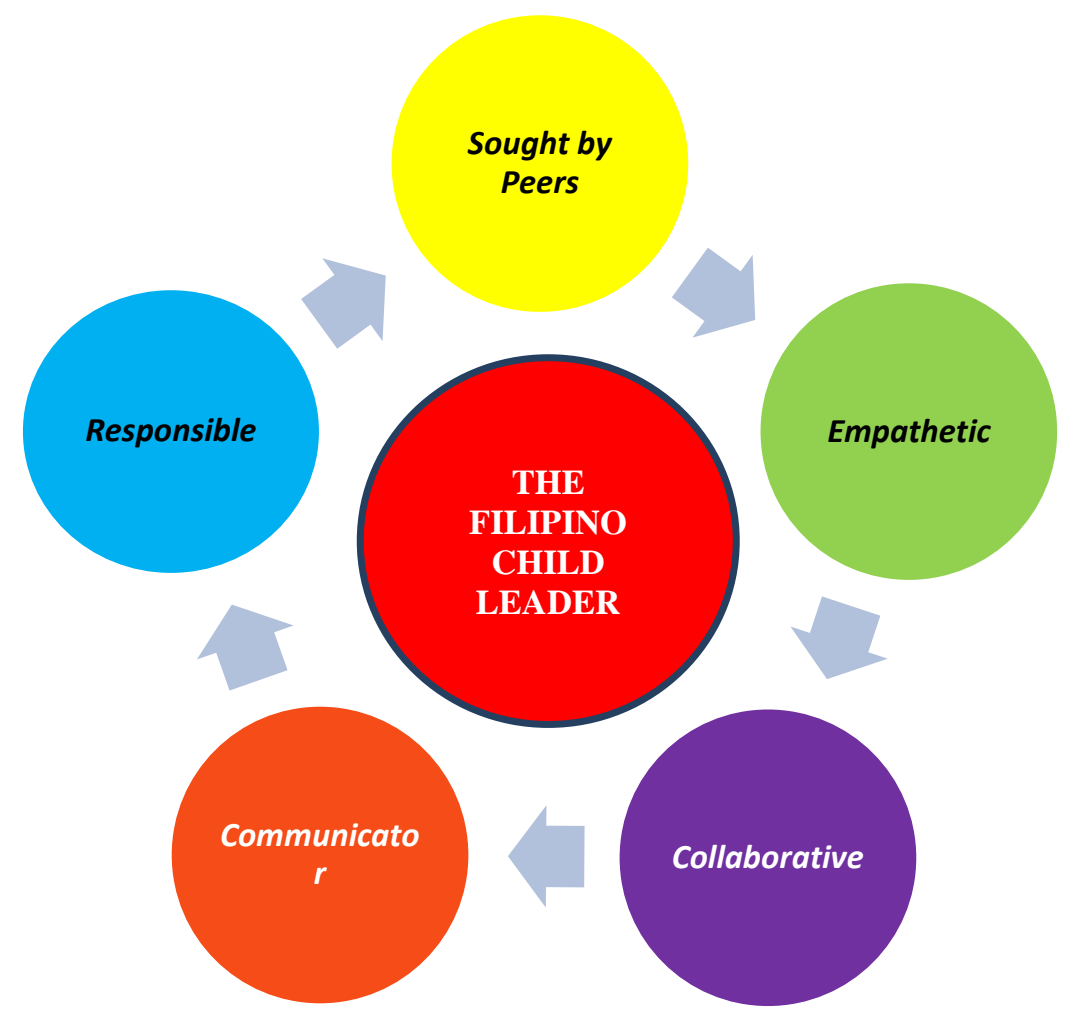

Being empathetic is a distinct characteristic of a Filipino child leader. He is not only smart but he also has concern for others. A child leader gets along well with others and is respectful and not offensive to others. This is characterized by the color green. The color green is full of balance and harmony. From a color psychology perspective, it's the color green, that puts heart and emotions in balance, and equals head and heart. The green color is an emotionally positive color, which gives us the ability to love and care for ourselves and others unconditionally. The color green has a strong sense of right and wrong and good judgment.

Having good communication and reasoning skills is another characteristic of a Filipino child leader. He expresses his ideas confidently and makes good choices and opinions. He gives valuable suggestions and does follow given instructions. This is pictured by the color orange. The color orange relates to social communication and it encourages two-way conversation. It is a warm and welcoming color that is both physically and mentally stimulating. It makes people think as well as speak. The color orange is optimistic and uplifting - it lifts our spirits. It adds spontaneity and a positive way of looking at life

Being collaborative and cooperative signifies a Filipino child leader. He responds and adapts well to different

situations. He works well independently or with others collaboratively. This is represented by the color purple. Purple ensures harmony of the mind and the emotions and contributes to mental balance and stability, peace of mind, a connection between the spiritual and physical world, and between thought and action. It inspires unconditional and selfless love and promotes sensitivity and compassion.

With the recognition and identification of child leadership characteristics, teachers can encourage the positive social and emotional growth of the learners. Teachers can help learners build their leadership confidence by providing opportunities and appropriate programs and activities. Fox et al. (2015) noted that educators who recognize child leadership characteristics from multiple domains will be more effective at nurturing children's leadership behaviors. As the domains overlap, one characteristic may be representative of more than one domain. Accordingly, Sad and Sahiner (2016) mentioned that it is necessary to determine the opinions of teachers regarding the applicability levels of the activities that can be performed for the acquisition of leadership qualities by students, who will take place in different fields in the future, for the sustainability of these developments. 


\section{Conclusions}

The study explores the early childhood education teachers' recognition of leadership characteristics among Filipino Kindergarten pupils. The results of this study will fill an important gap in the current literature on the importance of recognizing and enhancing leadership skills among young Filipino children. The results of the study would aid preschool teachers to identify, support, and encourage the leadership behaviors of the learners. This will give the teachers the acknowledgment to better address the children's needs and guide them to develop holistically. Similarly, this study will also equip the curriculum developers and program directors to recognize the need for more child-directed activities, including play, to allow children to practice leadership behaviors. The study could inspire training programs to prepare early childhood teachers to recognize and support leadership behaviors. Considering this study is exploratory in nature, parallel studies on teachers' perception and enhancement programs on child leadership would be contributory in the field of research. Furthermore, studies employing Factor Analysis on the instrument to corroborate the result would be supplementary in the available literature on child leadership. Additionally, studies utilizing available software on qualitative analysis of data is highly recommended. And more importantly, analysis of the developmentally appropriate activities in the classrooms to nurture the leadership potentials of the learners is proposed.

Since there is a current emphasis on 21st- century skills, which include personal as well as academic knowledge, it is just right to discover the possibility of exploring preschoolers' leadership skills which are beneficial to the domain of early education. With the wide application of collaborative and cooperative learning in school settings, it becomes increasingly important to understand the mechanisms by which children develop the skills and knowledge to work productively with others. Early childhood teachers need to realize how important it is to teach and encourage young learners' emerging leadership skills and teachers must be aware that they have a strong influence on young learners. The researcher believes that the growth of positive social-leadership traits in young children could be encouraged through the enhancement of the teaching skills of Filipino preschool teachers, and therefore, the delivery of quality education in the kindergarten level.

\section{Acknowledgments}

The researcher would like to thank the teacherparticipants for their contribution for the success of this study.

\section{Funding Source}

This research did not receive any outside funding or support.

\section{Conflicts of Interests}

The author declares that there is no conflict of interests.

\section{References}

Abdigapbarova, U. M.,

Baikulova, A. M., Shalabayeva, L. I., \& Zhundybayeva, T. N (2016). Communication through dialogue between preschool children with leadership skills. International Electronic Journal of Mathematics Education, 11(5), 1343-1350. https://www.iejme.com/download/communicati on-through-dialogue-between-preschoolchildren-with-leadership-skills.pdf

Alzahrani, M. A. (2018). The learning experience of international students in Canada: Progressive educational theory and passive learning styles. English Language Teaching, 11(7), 76-85. https://doi.org/10.5539/elt.v11n7p76

Barthold, S. K. (2014). The emergence of leadership in children: The role of play, athletics, and school [Master's thesis, Claremont McKenna College]. CMC Senior Theses. http://scholarship.claremont.edu/cmc_theses/85 9

Berman, E. A. (2017). An exploratory sequential mixed methods approach to understanding researchers' data management practices at UVM: Integrated findings to develop research data services. Journal of eScience Librarianship, 6(1), e1104. https://doi.org/10.7191/jeslib.2017.1104

Boas, S., House, R. J. \& Arthur, M. (2014). The motivational effects of charismatic leadership. A self-concept base theory. Organizational Science, $\quad 4(4), \quad 577-594$. https://doi.org/10.1287/orsc.4.4.577

Bradberry, T. (2015). 8 powerful ways to mold your children into leaders. Forbes. https://www.forbes.com/sites/travisbradberry/20 15/08/11/8-powerful-ways-to-mold-yourchildren-into-leaders/?sh=1941826c4ff4

Cansoy, R. (2017). The effectiveness of leadership skills development program for university students. Journal of History Culture and Art Research, 6(3), 65-87. https://doi.org/10.7596/taksad.v6i3.899

Cimene, F. T. A., \& Aladano, A. N. (2013). Leadership perspective from the Philippines: Its implications for theory, research and practice. In J. Rajasekar, \& L. S. Beh (Eds.), Culture and Gender in Leadership (pp. 48-63). Palgrave Macmillan. https://doi.org/10.1057/9781137311573_4

Department of Education, Republic of the Philippines. (2012). K to 12 curriculum guide kindergarten. https://eedncr.files.wordpress.com/2012/06/kind ergarten-curriculum-guide.pdf

Epstein, A. S. (2014). The intentional teacher: Choosing the best strategies for young children's learning. The National Association for the Education of Young Children. https://eric.ed.gov/?id=ED497633

Evans, S. E. (2014). Making leaders: Examining how elementary school students develop an understanding of leadership and show emerging 
leadership tendencies [Doctoral dissertation]. Virginia Commonwealth University Scholars Compass. https://doi.org/10.25772/NHW2-J833

Ferland, A., Chu, Y., Gleddie, D. \& Veugelers, P. (2015). Leadership skills are associated with health behaviours among Canadian children. Health Promotion International, 30(1), 106113. https://doi.org/10.1093/heapro/dau095

Fox, D., Flynn, L. \& Austin, P. (2015). Child leadership: Teachers' perceptions and influences. Childhood Education, 91(3), 163168.

https://doi.org/10.1080/00094056.2015.1047306

Francis, G. L., Blue-Banning, M., Turnbull, A. P., Hill, C., Haines, S. J., \& Gross, J. M. S. (2016). Culture in Inclusive Schools: Parental Perspectives on Trusting Family-Professional Partnerships. Education and Training in Autism and Developmental Disabilities, 51(3), 281293. http://www.jstor.org/stable/24827524

Gunindi, Y. (2017). Preschool children's perceptions of the value of affection as seen in their drawings. International Electronic Journal of Elementary Education, $\quad$ 7(3), 371-382. https://www.iejee.com/index.php/IEJEE/article/ view/86

Ilac, E. J. (2011, January 31). What makes a Filipino leader? Philippine Daily Inquirer. https://www.pressreader.com/philippines/philip pine-daily-inquirer-

1109/20110131/286517269518004

Labor, J. (2017). Filipino student council heads' leadership frames. The Journal of Student Leadership, $\quad 1 \quad$ (1), 25-35. https://journals.uvu.edu/index.php/jsl/article/vie w/7

Laygo-Saguil, J. (2020). Leadership in young Filipino children survey (LYFCS). Globus Journal of Progressive Education, 10(2), 55-59. https://www.globusedujournal.in/wpcontent/uploads/2020/11/GE-JD208-JuzyLaygo-Saguil.pdf

Montgomery, A., \& Kehoe, I. (Eds.). (2015). Reimagining the purpose of schools and educational organizations. Springer. https://doi.org/10.1007/978-3-319-24699-4
Mulovhedzi, S. A. \& Mudzielwana, N. P. (2016). Importance of teaching leadership skills in the foundation phase. International Journal of Educational Sciences, 13(2), 202-207 https://doi.org/10.1080/09751122.2016.1189045 4

Oguz, V., \& Akyol, A. K. (2014). A study on problem solving skills of children attending nursery school. International Journal of Social Sciences and Education, 4(2), 392-400. https://www.academia.edu/30982171/A_Study_ on_Problem_Solving_Skills_of_Children_Atten ding_Nursery_School

Oliveira, K. A. C. (2016). Children's implicit leadership theories in middle childhood: Christian children's perceptions in the Cavite province. Journal of Research on Christian Education, 25(3), 251-272. https://doi.org/10.1080/10656219.2016.1237908

Sad, S. N., \& Sahiner, Y. K. (2016). Temel eğitimden ortaöğretime geçiş (TEOG) sistemine ilişkin öğrenci, öğretmen ve veli görüşleri [Views of students, teachers and parents on the transition system from basic education to secondary education]. Elementary Education Online, 15(1). https://doi.org/10.17051/io.2016.78720 [in Turkish]

Yacat, J. (2013). Filipino psychology (Sikolohiyang Pilipino). In K. D. Keith (Ed.), The Encyclopedia of Cross-Cultural Psychology (pp. 551-556). John Wiley \& Sons. https://doi.org/10.1002/9781118339893.wbeccp 224

Zembat, R., Gök Çolak, F., \& Günşen, G. (2017). A program suggestion on leadership in early childhood "Descrier child descried leadership education program". In I. Koleva, \& G. Duman (Eds.), Educational Research and Practice (pp. 46-53). St. Kliment Ohridski University Press. https://www.academia.edu/37204348/EDUCAT IONAL_RESEARCH_AND_PRACTICE

Zepp, R. A. (2018). Perceptions of good and bad leaders by Philippine teachers. Journal of Management and Strategy, 9(1), 66-81. https://doi.org/10.5430/jms.v9n1p66

\footnotetext{
Анотація

Вступ: У иьому дослідженні вивчається визнання педагогами дошкільної освіти лідерських якостей філіппінських вихованиів дитсадків. Це дослідження, засноване на теорії Дьюї про прогресивну освіту, покликане заповнити прогалину в літературі, присвяченій лідерським якостям та поведіниі дітей.

Мета: Визначити, як педагоги у дошкільних закладах розпізнають лідерську поведінку маленьких дітей.

Матеріали і Методи: Для широкого вивчення та аналізу сприйняття педагогів дитячого садка лідерства дітей обрано попереднє послідовне дослідження змішаними методами. При изьому застосовувався описовий дизайн дослідження з використанням як якісних, так і кількісних даних. Обговорення у фокус-групах уперше проведено з 10 учителями приватних шкіл для якісної частини дослідження. За наслідками обговорення підготовлено 25 питань лідерства в опитуванні дітей раннього віку. Опитування оцінювалося 3 використанням формату відповіді типу Лайкерта. У кількісній частині взяли участь 95 освітян центру дитячого розвитку, відібраних методом цілеспрямованої вибірки.

Результати: Результати показали, щуо дескриптори лідерства, щчо з'явилися на основі обговорення у фокусгрупі, включають: затребуваність однольтками, відповідальність, чуйність, комунікативність та співпрацю.
} 
Ці дескриптори стали основою розробки моделі дитячого лідерства філіппінської системи дитячого лідерства.

Висновки: Розвиток позитивних соціально-лідерських якостей у дітей молодшого віку можна стимулювати за рахунок підвищення педагогічних навичок філіппінських педагогів дошкільних закладів та, отже, надання якісної освіти на рівні дитячого садка.

Ключові слова: дослідницькі послідовні змімані методи, педагоги дитячого садка, лідерство, маленькі філіппінські діти, освіта, опитування.

\section{Аннотация}

Введение: В этом исследовании изучается признание педагогами дошкольного образования лидерских качеств филиппинских воспитанников детских садов. Это исследование, основанное на теории Дьюи о прогрессивном образовании, призвано заполнить пробел в литературе, посвященной лидерским качествам и поведению детей.

Цель: Определить, как педагоги в дошкольных учреждениях распознают лидерское поведение у маленьких demeй.

Материалы и Методы: Для широкого изучения и анализа восприятия педагогов детского сада лидерства детей выбрано предварительное последовательное исследование смешанными методами. При этом применялся описательный дизайн исследования с использованием как качественных, так и количественных данных. Обсуждение в фокус-группах впервые проведено с 10 учителями частных школ для качественной части исследования. По результатам обсуждения подготовлено 25 вопросов лидерства в опросе детей раннего возраста. Опрос оченивался с использованием формата ответа типа Лайкерта. В количественной части приняли участие 95 педагогов центра детского развития, отобранных методом целенаправленной выборки.

Результаты: Результаты показали, что дескрипторы лидерства, появившиеся на основе обсуждения в фокусгруппе, включают: востребованность сверстниками, ответственность, чуткость, коммуникативность и сотрудничество. Эти дескрипторы легли в основу разработки модели детского лидерства филиппинской системы детского лидерства.

Выводы: Развитие положительных сочиально-лидерских качеств у детей младшего возраста можно стимулировать за счет повышения педагогических навыков филиппинских педагогов дошкольных учреждений и, следовательно, предоставления качественного образования на уровне детского сада.

Ключевые слова: исследовательские последовательные смешанные методы, педагоги детского сада, лидерство, маленькие филиппинские дети, образование, опрос.

The electronic version of this article is complete. It can be found online in the IJES Archive https://ijes.world/en/archive and in the KRPOCH Publishing Repository https://ekrpoch.culturehealth.org/handle/lib/58 